This document was prepared in conjunction with work accomplished under Contract No. DE-AC09-96SR18500 with the U.S. Department of Energy.

This work was prepared under an agreement with and funded by the U.S. Government. Neither the U. S. Government or its employees, nor any of its contractors, subcontractors or their employees, makes any express or implied: 1 . warranty or assumes any legal liability for the accuracy, completeness, or for the use or results of such use of any information, product, or process disclosed; or 2 . representation that such use or results of such use would not infringe privately owned rights; or 3 . endorsement or recommendation of any specifically identified commercial product, process, or service. Any views and opinions of authors expressed in this work do not necessarily state or reflect those of the United States Government, or its contractors, or subcontractors. 
WSRC-TR-2005-00433

\title{
Comparison of Air and Deuterium on Pinch Weld Bond Appearance
}

\author{
By
}

P.S. Korinko

September 2005

Westinghouse Savannah River Company

Aiken, SC 29808

Prepared for the U.S. Department of Energy under Contract DE-AC09-96SR18500 
Comparison of Air and Deuterium on $\quad$ Page ii $\quad$ WSRC-TR-2005-00433

Pinch Weld Bond Appearance

WSRC-RP-2005-00433

MST

MATERIALS SCIENCE and TECHNOLOGY

\author{
Keywords: $\quad$ Stainless steel \\ Fill Stems \\ Pinch welds
}

Retention: Permanent

\title{
Comparison of Air and Deuterium on Pinch Weld Bond Appearance
}

\author{
By \\ P.S. Korinko \\ Materials Compatibility and Welding Technology Group
}

ISSUED: $\quad$ September 2005

SRNL SAVANNAH RIVER NATIONAL LABORATORY, AIKEN, SC 29808 Westinghouse Savannah River Company

Prepared for the U.S. Department of Energy under Contract DE-AC09-96SR18500 
Document: $\quad$ WSRC-TR-2005-00433

Title: Comparison of Air and Deuterium on Pinch Weld Bond Appearance

APPROVALS

$9-20-05$

P.S. Korinko, Author

Date

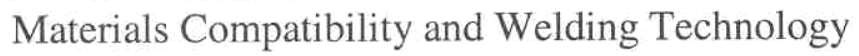

]

9-20-05

W.L. West, Technical Reviewer

Date

Reservoir Systems Engineering

S.L. West, Manager

$9 / 22 / 2005$

Materials Compatibility and Welding Technology

N.C. Iyer, Manlager

$\frac{10707 / 2005}{\text { Date }}$

Date 


\title{
Comparison of Air and Deuterium on Pinch Weld Bond Quality
}

\begin{abstract}
The effect that air and deuterium internal atmospheres have on the pinch weld bond quality was evaluated by conducting a scoping study using type 304L stainless steel LF-7 test stems that were fabricated for an associated study. Welds were made under cool, yet nominal conditions to exacerbate the influence of the atmosphere. The bond quality of the welds was directly related to the internal atmosphere with the air atmosphere welds being of lower quality than the deuterium atmosphere welds for nominally identical welding conditions.
\end{abstract}

\section{Background}

Tritium reservoirs are welded with an internal pressure of hydrogen isotopes, qualification welds in the inert facilities are often welded in air and the results transferred to the appropriate facility. Historical document and precedent indicate that the bond quality will increase by a fraction of a bond rating when going from air to an inert or hydrogen gas $(1,2)$. This activity was undertaken to try to quantify and revalidate the change. Type 304L stainless steel stems manufactured by the Kansas City Plant (KCP) were utilized in this study. These stems were fabricated as part of a larger ADAPT task that is evaluating the influence of manufacturing and pinch weld processing on pinch weld quality. The stems were machined at similar parameters and aqueous cleaned at KCP. Four stems were used in this study and all were welded at low current conditions that would produce acceptable, but less than ideal weld quality, to try to better elucidate the influence of the atmosphere.

Welds were made using the SRNL pinch welder in 723-A at a force of $1250 \mathrm{lbs}$, a current of $3700 \mathrm{~A}$, in voltage control mode, and 12 cycles. The welds were made in the vertical orientation with a simulated LF-7 mass and LF-7 fixturing. The weld head and fixturing are shown in Figure 1. The welds were made using an internal gas of either $15 \mathrm{psig}$ ( $2 \mathrm{~atm})$ deuterium or air after evacuating the system to about -28 inches of water and backfilling once.

The samples were measured for thickness and width, x-ray radiographed for weld anomalies, closure length, and extrusion geometry, and examined metallographically for bond quality in the as-polished and oxalic acid etched condition.

\section{Results}

The samples were welded using the conditions listed in Table 1. The weld voltage, current and force were close to the desired target values. The post weld resistance is consistent with other welds made using these conditions. All of the samples were welded within 10 amperes of the target. The weld thickness and width were consistent between samples, as expected for samples 
welded using nominally the same conditions and set-up. The in-process, net displacement, for sample X0069 was lower than expected, despite being welded with nominally the same weld conditions as the other stems. All of the stems meet defense programs (DP) requirements for closure length and weld geometry, i.e., extrusion or root radius.

All of the welds were examined radiographically with the results shown in Figure 2. These face and side view radiographs exhibit the expected conditions. There is no evidence of the interface for either the air or deuterium internal atmospheres. As expected for a cold weld, there is little or no extrusion. An interesting item of note is that the closure length was systematically lower for the air welded sample compared to the deuterium welded sample for these four stems.

The metallographic inspection of the samples was conducted by first examining the samples in the as-polished condition then etching them electrolytically with $10 \%$ oxalic acid. The aspolished condition is shown in Figure 3 for the air and deuterium internal atmosphere welds. The weld interface is visible on the samples welded in air while it is not visible for the samples welded with deuterium. The samples were then etched and photomicrographs were taken at 50 to 500X. These images are shown in Figures 4 to 7, for the various samples. It is apparent from these photos that there is a difference between the air and deuterium atmospheres. The air sample has a continuous bond line in evidence as noted in Figures 4d, 4e, 5d and 5e for the center of the weld as well as the edge or what is sometimes referred to as the "crows foot" of the weld, and indicated by the arrow in Figure 4a. A discontinuous bond line is visible in the samples welded in deuterium, Figure 6d, 6e and 7d. Grain growth across the interface is evident in all the samples.

Figure 8 shows is a direct comparison of the micrographs shown in Figures $4 \mathrm{~d}$ and $7 \mathrm{~d}$. It is obvious that the bond line is more prominent in the air welded sample than in the deuterium welded sample. The bond line is continuous vs. discrete for air vs. deuterium. Based on these images, there is a finite difference between the two atmospheres. It is difficult to assign quantitative value in terms of bond rating between the two except to note that the air sample would be a class 3 bond and the deuterium weld would be a class 2 bond.

\section{Conclusions}

Relatively cool welds showed the expected difference in bond quality between an internal atmosphere of 15 psig air compared to an internal atmosphere of 15 psig deuterium.

Welding samples with an internal atmosphere of deuterium compared to air results in a visibly different bond quality. The bond line was continuous in the air welded samples and more discrete and intermittent in the deuterium welded samples. 
Comparison of Air and Deuterium on $\quad$ Page $3 \quad$ WSRC-TR-2005-00433

Pinch Weld Bond Appearance

\section{Acknowledgements}

The author would like to thank Bill West for his assistance in expediting the radiography and dimensional measurements. He would also like to express his gratitude to Tony Curtis for the rapid response for completing the metallography. He would also like to acknowledge Karl Arnold of the KCP for providing stems and expediting them through the ultrasonic testing being conducted by John Brunk also of the KCP.

\section{References}

1. DPSPWD 83-24-3, Pinch Welding (U), J. R. Harpring, May 1984 (Secret R-D).

2. DPSTWD 87-108, Difficulty in Obtaining Acceptable Test Welds (U), J.A. Davenport, January 30, 1987 (Secret R-D). 
Pinch Weld Bond Appearance

Table 1. Weld Conditions and machine data

\begin{tabular}{|c|c|c|c|c|c|c|c|c|c|c|c|}
\hline \multirow[t]{2}{*}{ Weld } & \multirow{2}{*}{$\begin{array}{l}\text { ATM } \\
\text { (30 psia) }\end{array}$} & \multicolumn{3}{|c|}{ Target } & \multicolumn{4}{|c|}{ Actual } & \multirow[t]{2}{*}{ Resistance } & \multirow{2}{*}{$\begin{array}{l}\text { Post } \\
\text { Res }\end{array}$} & \multirow[t]{2}{*}{ weld V } \\
\hline & & Voltage & Force & Current & Volatge & Force & Current & Pressure & & & \\
\hline X0067 & Air & 343 & 1250 & 3450 & 342.64 & 1264 & 3451.7 & 110.13 & & 0.221 & 0.77 \\
\hline X0068 & Air & 343 & 1250 & 3450 & 342.83 & 1290 & 3460.2 & 111.99 & 0.2718 & 0.215 & 0.74 \\
\hline X0069 & D2 & 343 & 1250 & 3450 & 342.8 & 1290 & 3456.3 & 112.08 & 0.2618 & 0.220 & 0.76 \\
\hline X0070 & D2 & 343 & 1250 & 3450 & 342.88 & 1264 & 3453.1 & 109.94 & 0.2784 & 0.224 & 0.77 \\
\hline
\end{tabular}

Table 2. Weld quality information

\begin{tabular}{|c|c|c|c|c|c|c|c|c|c|c|}
\hline Weld & $\begin{array}{l}\text { ATM } \\
(30 \text { psia) }\end{array}$ & Net Displ. & Thickness & Width & $\begin{array}{l}\text { Closure } \\
\text { length }\end{array}$ & $\begin{array}{l}\text { Max } \\
\text { Extrusion }\end{array}$ & $\begin{array}{l}\text { Extrusion } \\
\text { ratio }\end{array}$ & $\begin{array}{l}10 \mathrm{mil} \\
\text { Ball }\end{array}$ & $\begin{array}{l}\text { Bond } \\
\text { rating }\end{array}$ & Comments \\
\hline X0067 & Air & 0.018355 & 0.056 & 0.128 & 0.1362 & $\mathrm{~N} / \mathrm{A}$ & $\mathrm{N} / \mathrm{A}$ & 0.0190 & 3 & Almost continuous line \\
\hline X0068 & Air & 0.018291 & 0.056 & 0.127 & 0.1307 & $\mathrm{~N} / \mathrm{A}$ & N/A & 0.0140 & 3 & Almost continuous line \\
\hline X0069 & D2 & 0.015622 & 0.057 & 0.128 & 0.1384 & $\mathrm{~N} / \mathrm{A}$ & N/A & 0.0190 & 2 & Discontinuous line \\
\hline X0070 & D2 & 0.018378 & 0.056 & 0.127 & 0.1448 & 0.0016 & 0.09 & N/A & 2 & Discontinuous line \\
\hline
\end{tabular}




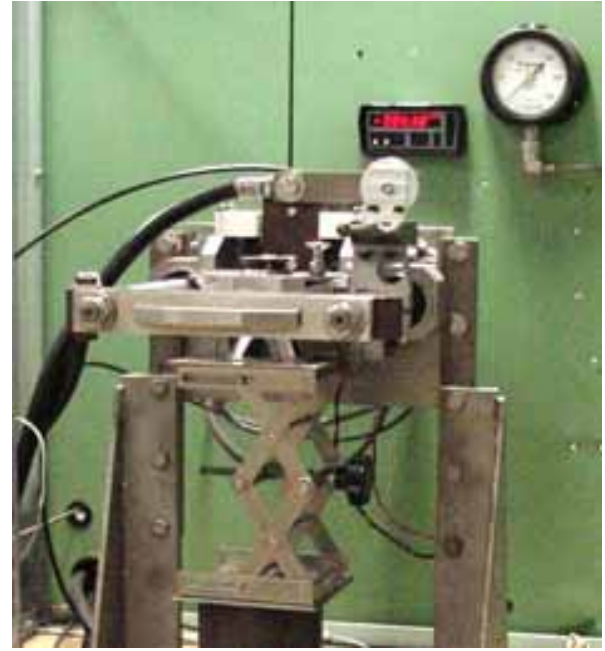

(a)

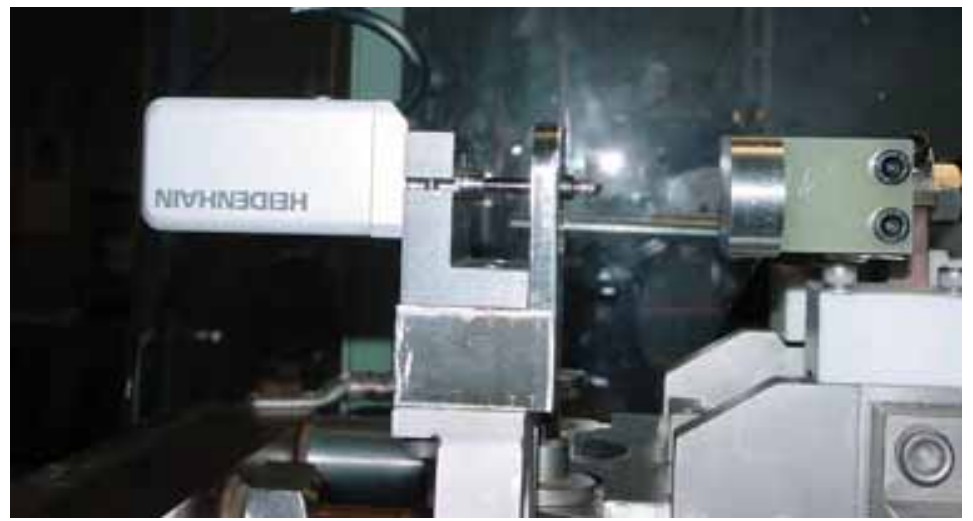

(b)

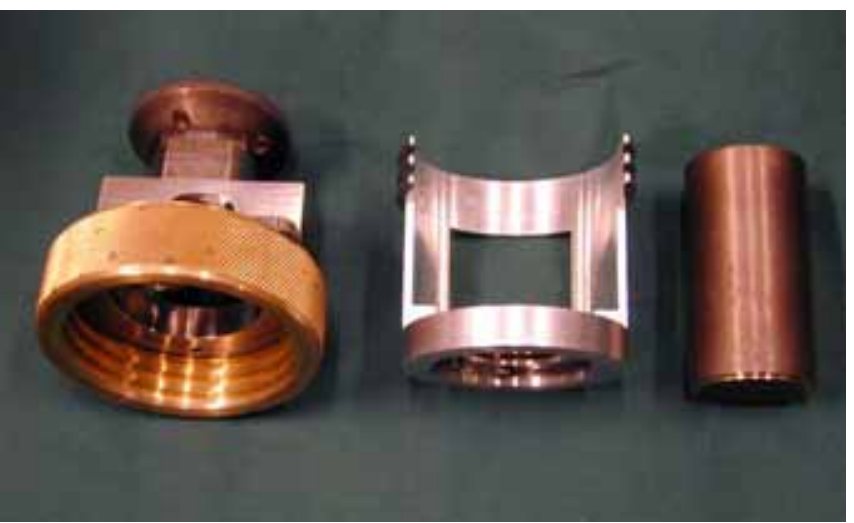

(c)

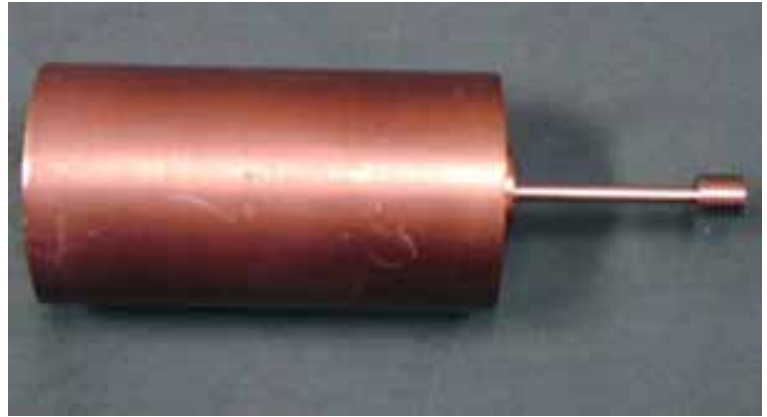

(d)

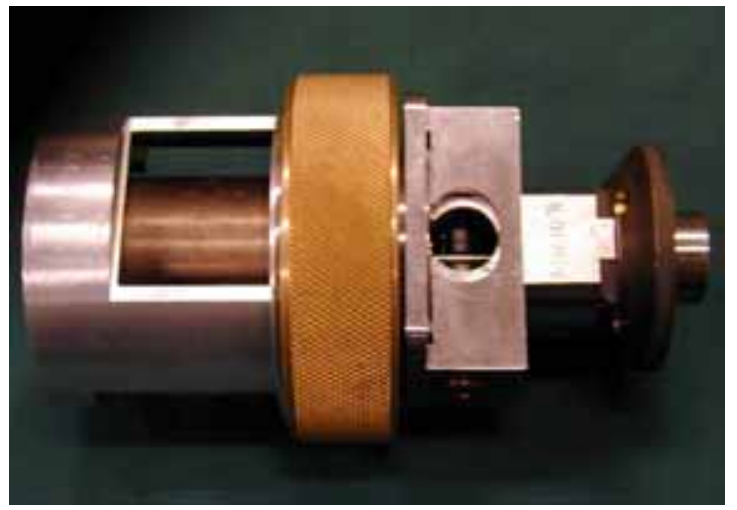

Figure 1. Weld equipment used (a) Weld head (b) displacement sensor and placement (c) assembly for welding (d) simulated LF-7 mass (e) fully assembled fixture including confining dies, "reservoir" and basket. 


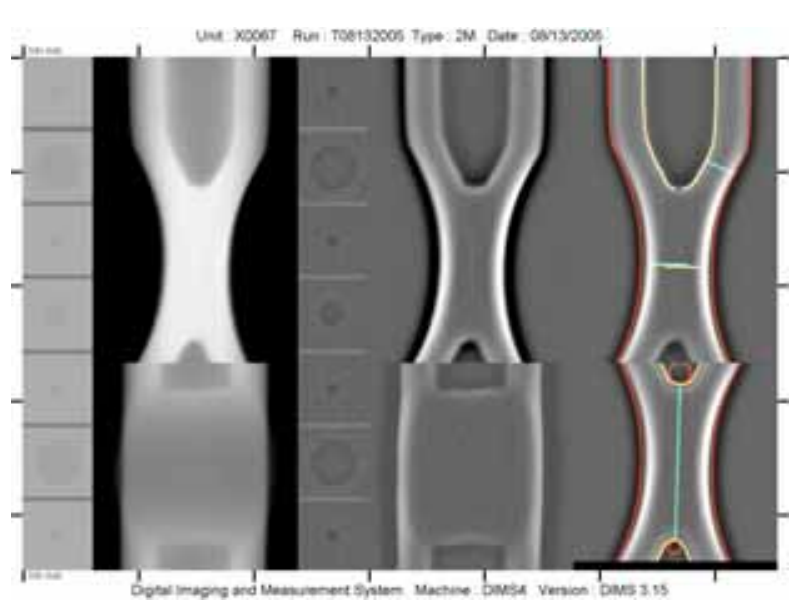

(a) $\mathrm{X} 0067$

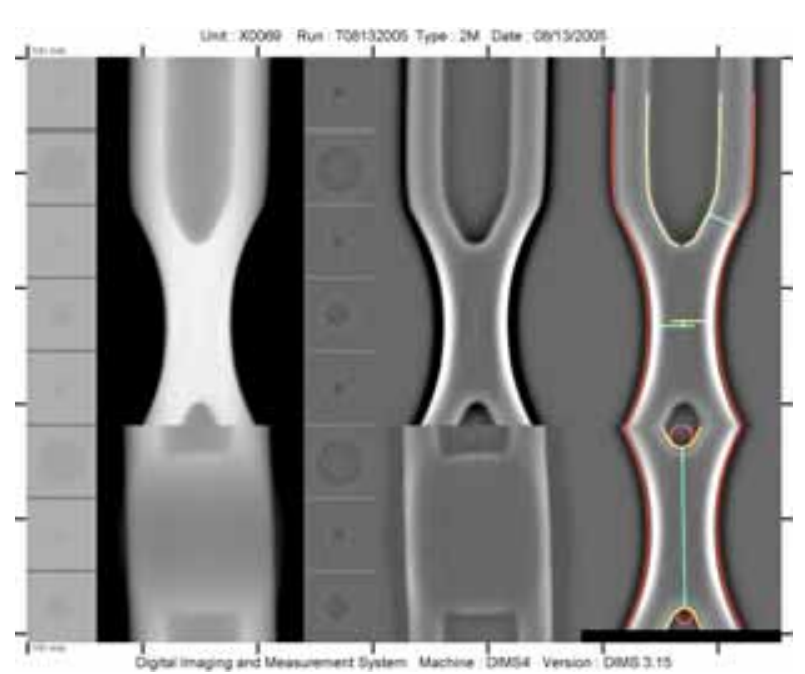

(c) X0069

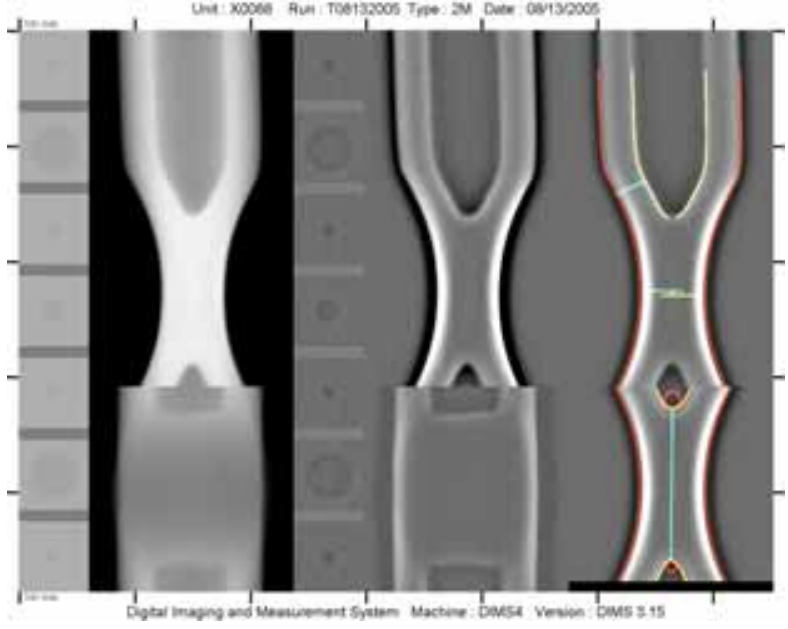

(b) X0068

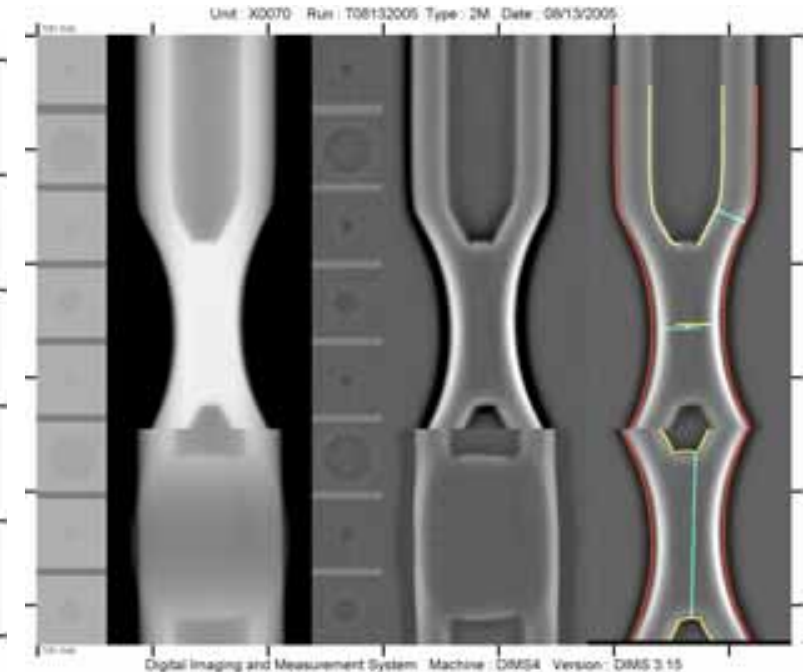

(d) X0070

Figure 2. Face and side view radiographs of welded stems (a) X0067 (b) X0068 (c) X0069 (d) X0070. Fiduciary marks, lines and circles, on right side x-ray image are used to indicate closure length, electrode alignment, wall thickness, and root radius not weld anomalies. 


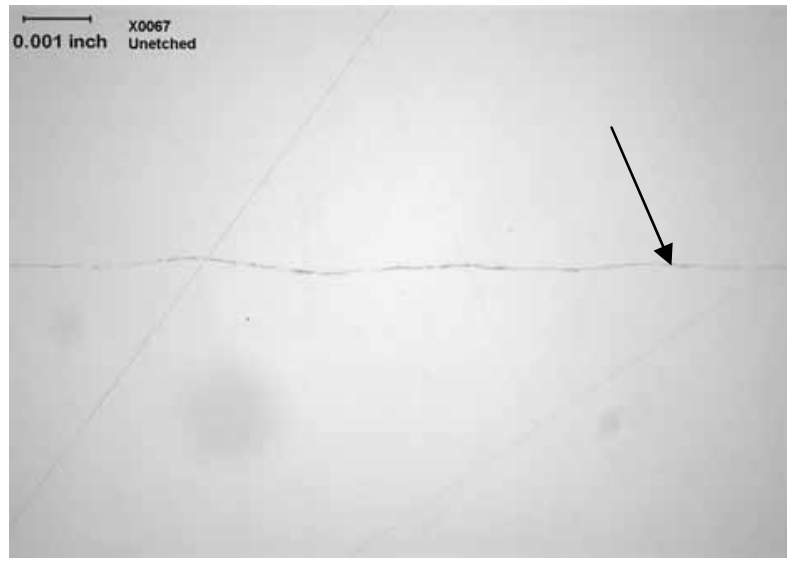

(a) X0067

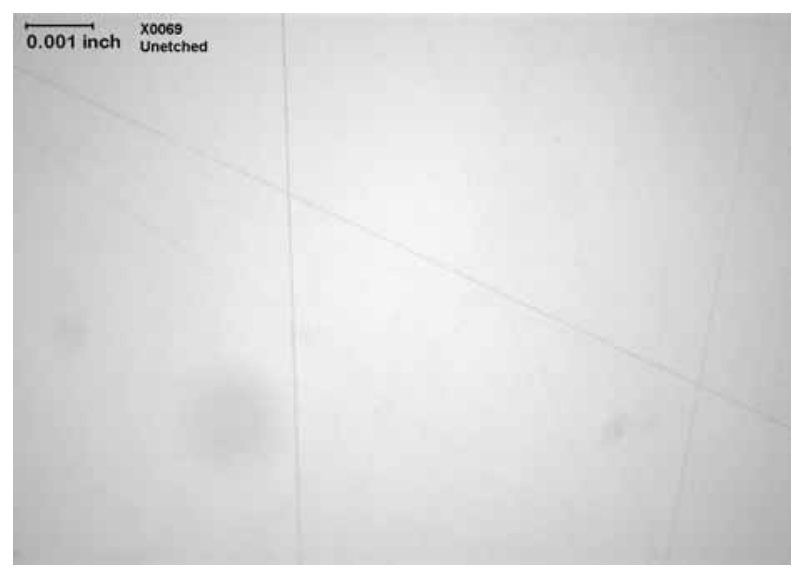

(c) X0069

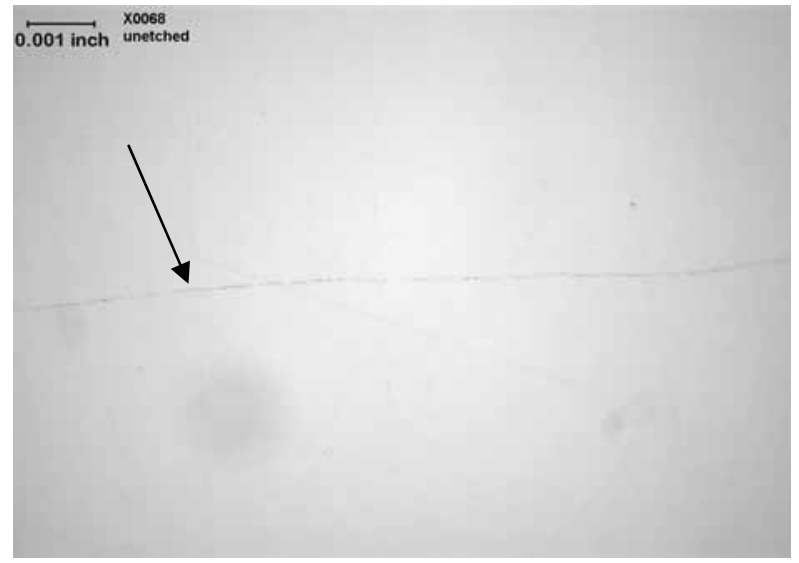

(b) X0068

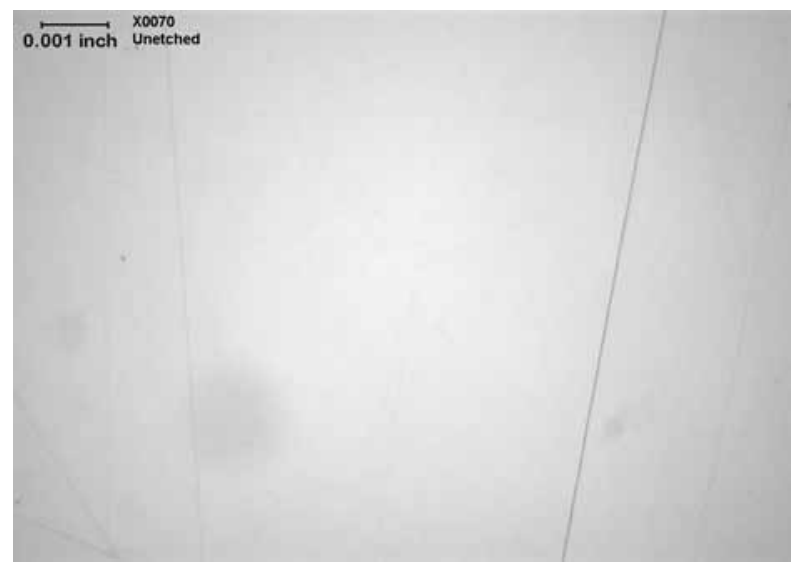

(d) X0070

Figure 3. As polished condition of (a) X0067 welded in air (b) X0068 welded in air (c) X0069 welded in deuterium (d) X0070 welded in deuterium, the arrow indicates the visible bond line. 


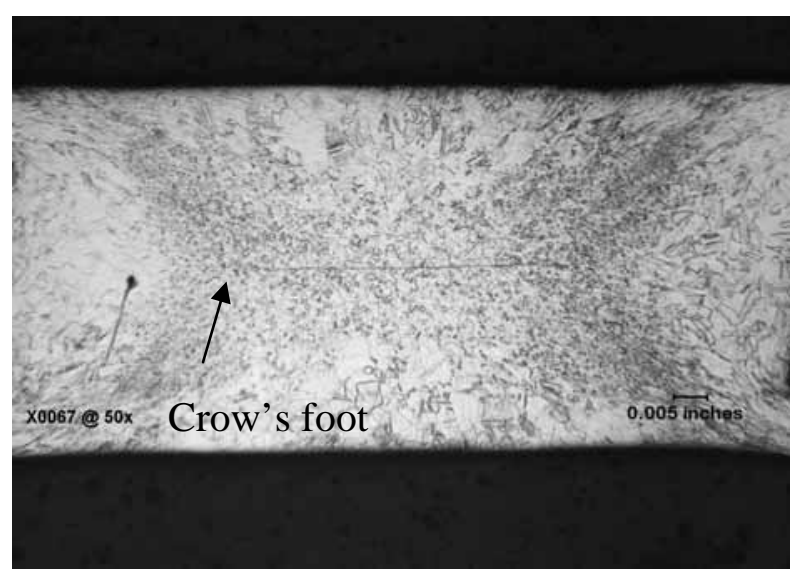

(a)

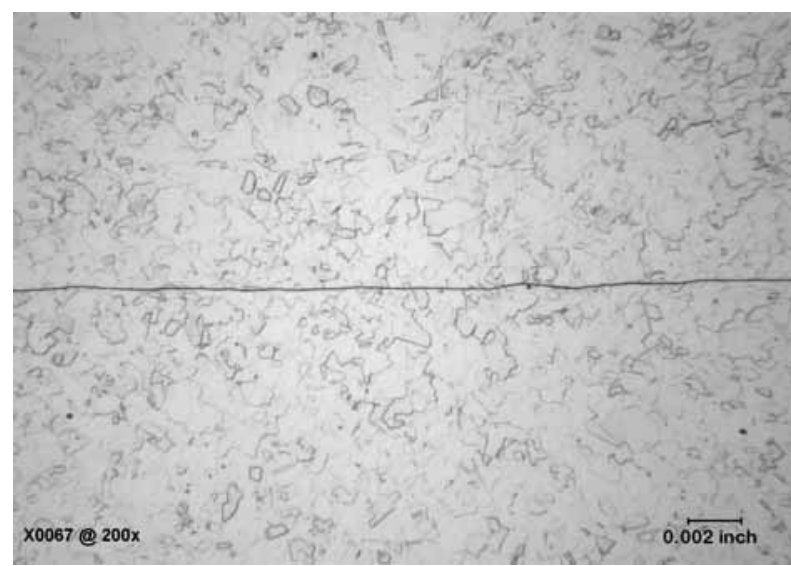

(c)

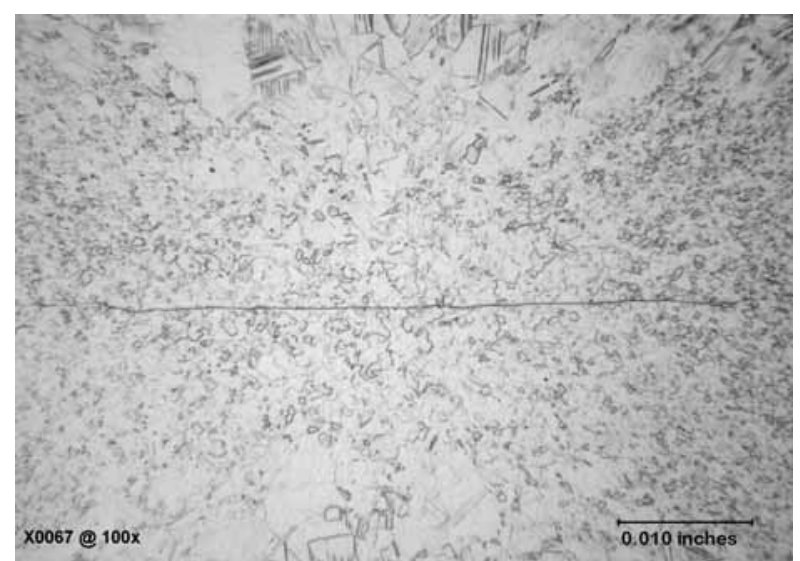

(b)

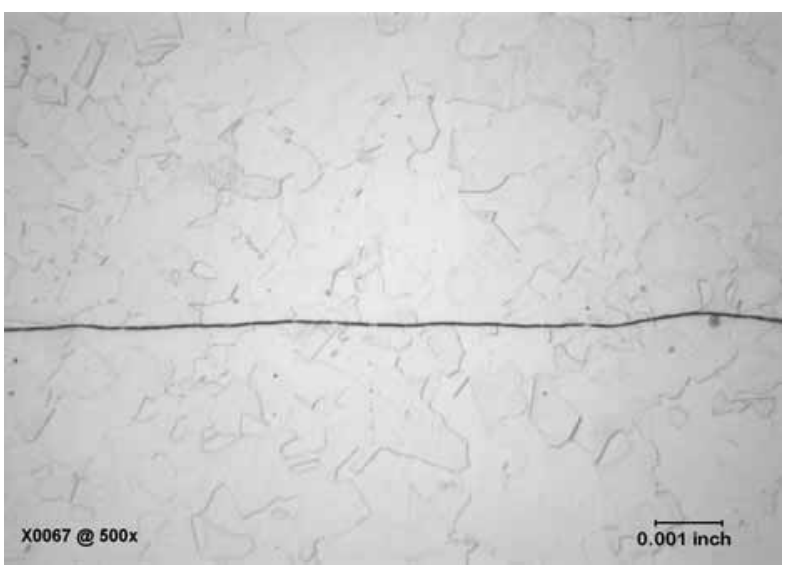

(d)

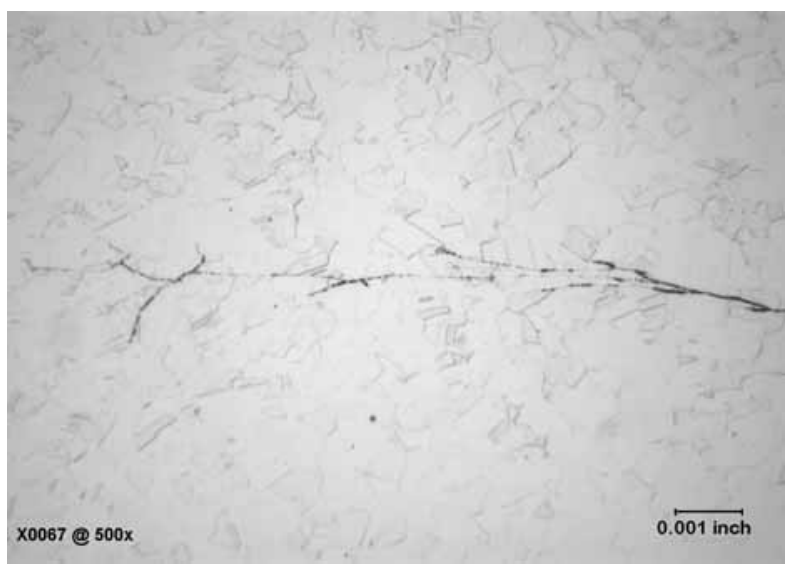

(e)

Figure 4. Sample X0067 welded in air, shown at various original magnifications (a) 50X (b) 100X, (c) 200X (d) 500X and (e) 500X in "crow's foot", as indicated by arrow in (a). 


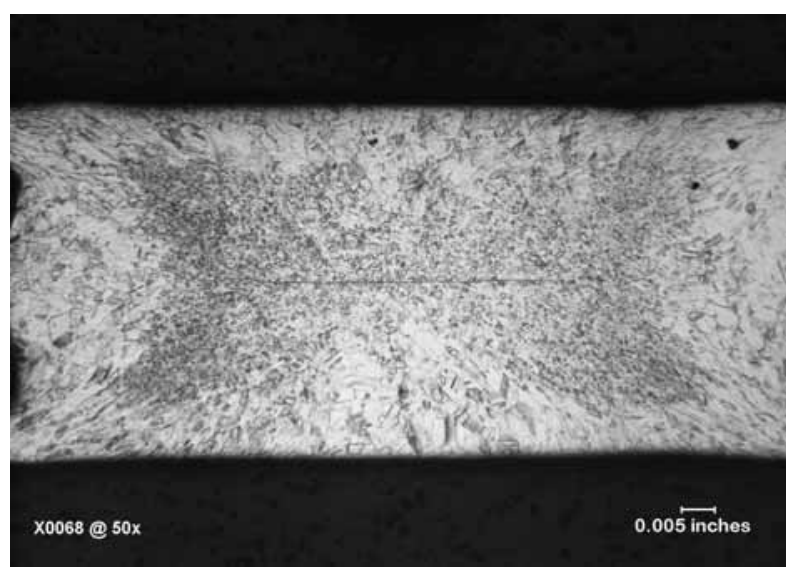

(a)

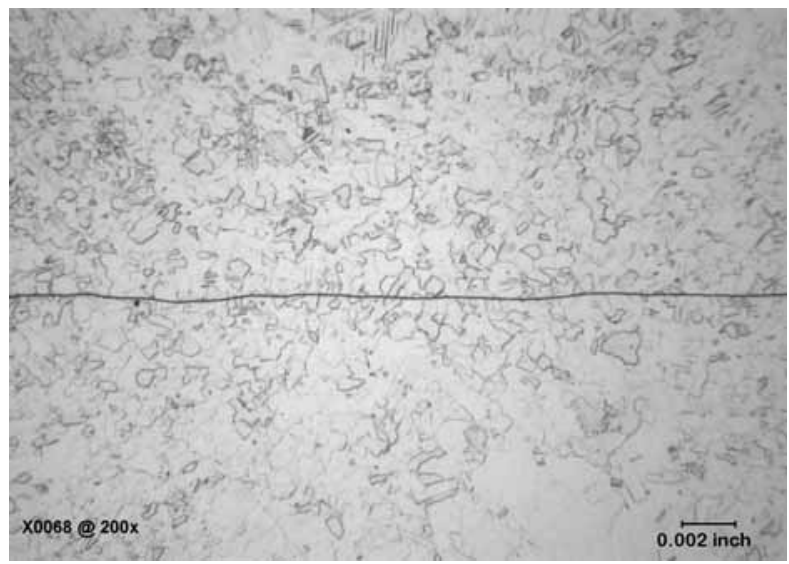

(c)

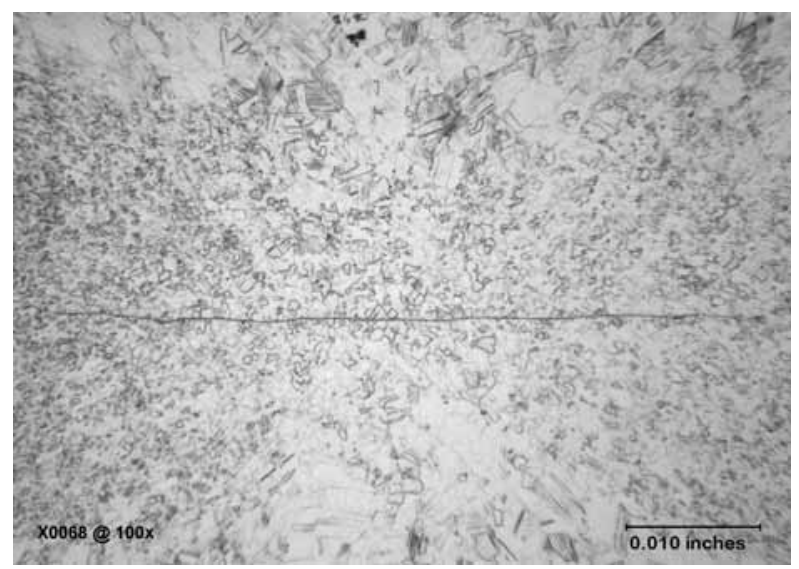

(b)

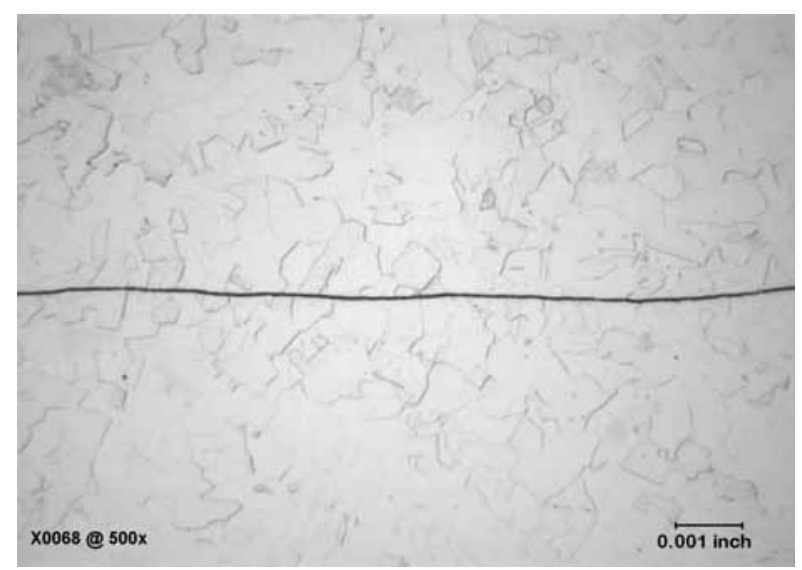

(d)

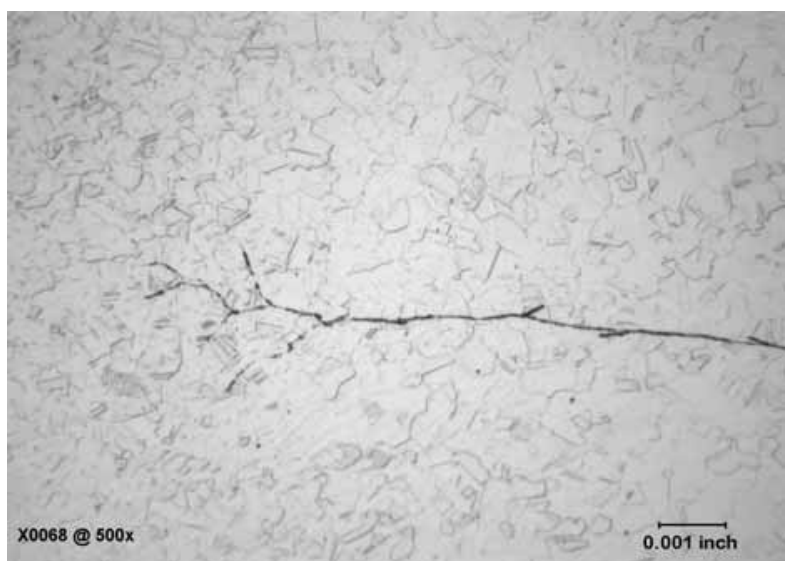

(e)

Figure 5. Sample X0068 welded in air, shown at various original magnifications (a) 50X (b) 100X, (c) 200X (d) 500X (e) $500 \mathrm{X}$ in crow's foot 


\section{Pinch Weld Bond Appearance}

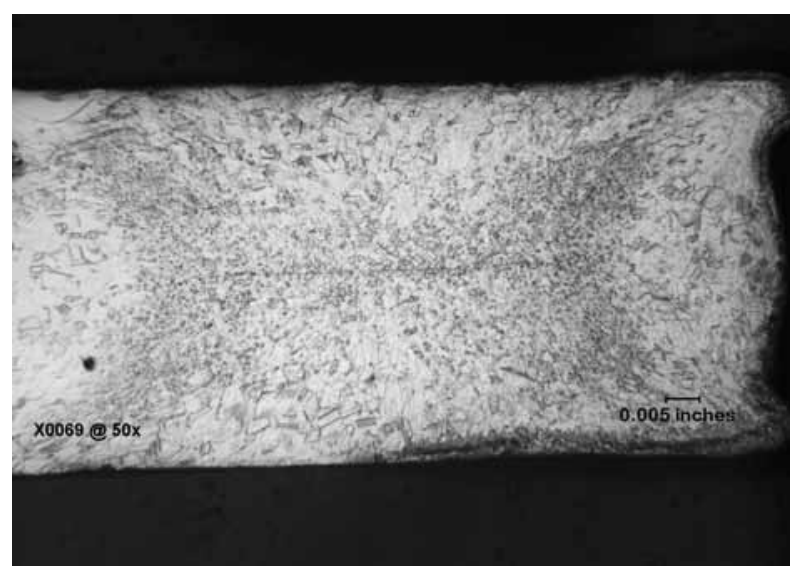

(a)

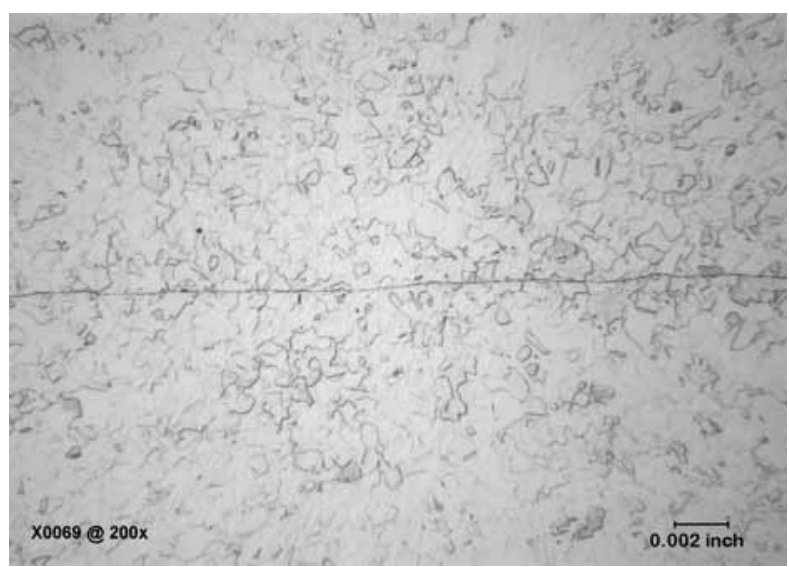

(c)

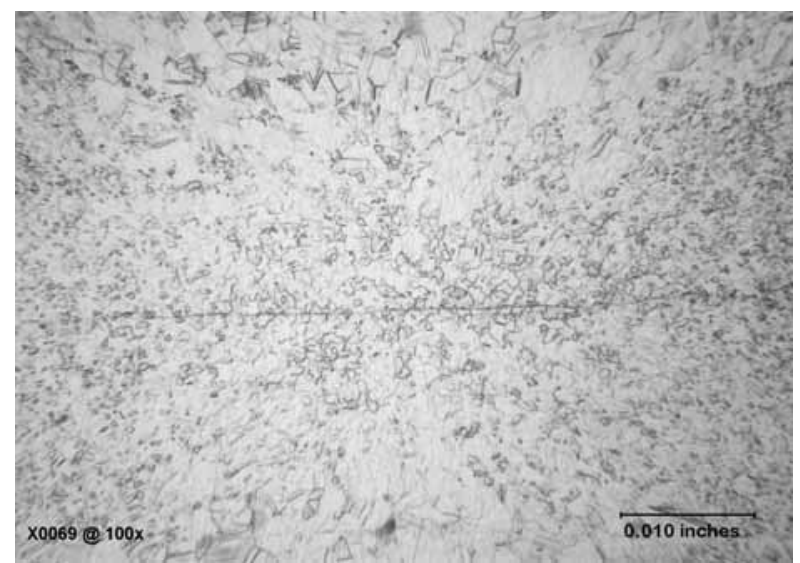

(b)

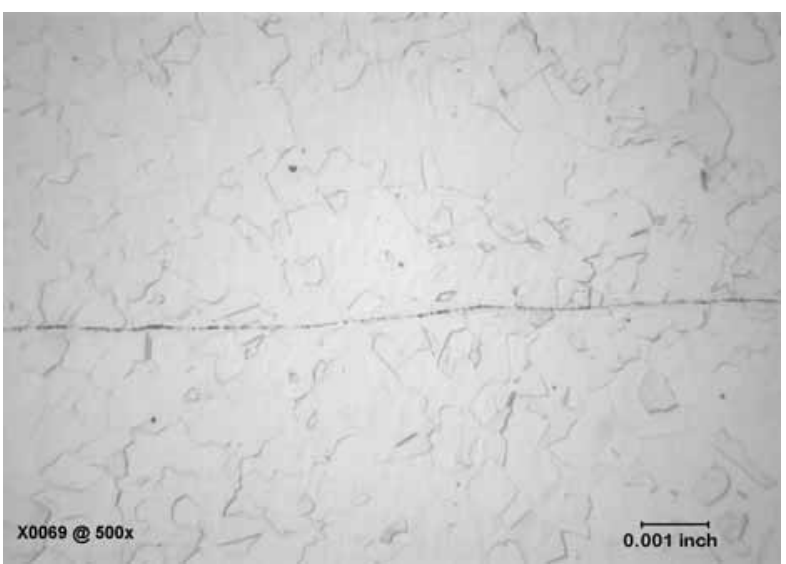

(d)

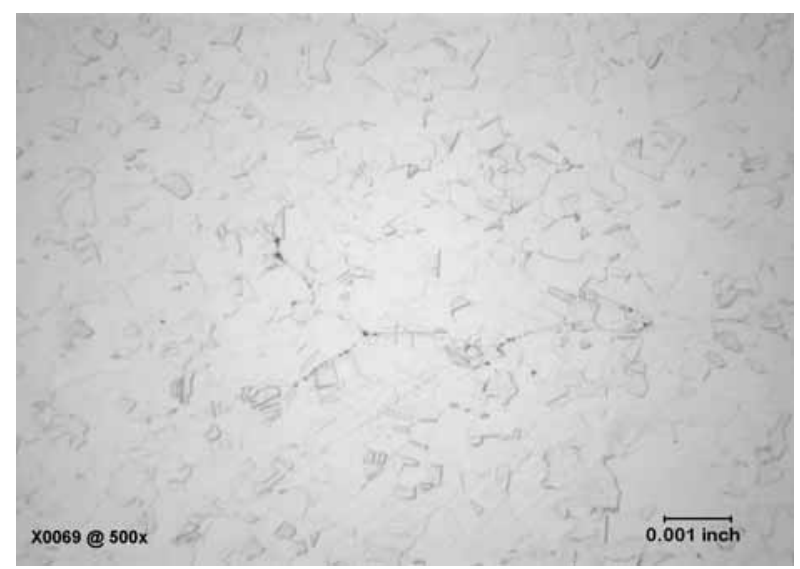

(e)

Figure 6. Sample X0069 welded in deuterium, shown at various original magnifications (a) 50X (b) 100X, (c) 200X (d) 500X and (e) 500X in crow's foot 


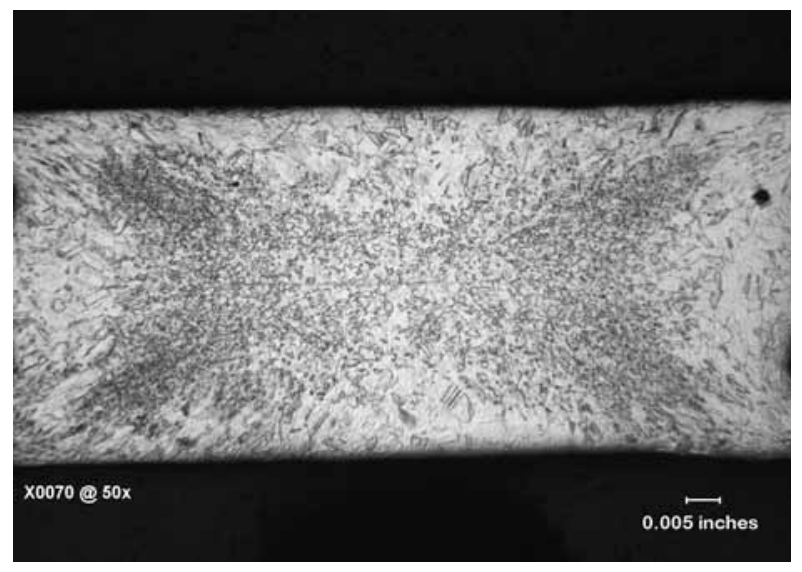

(a)

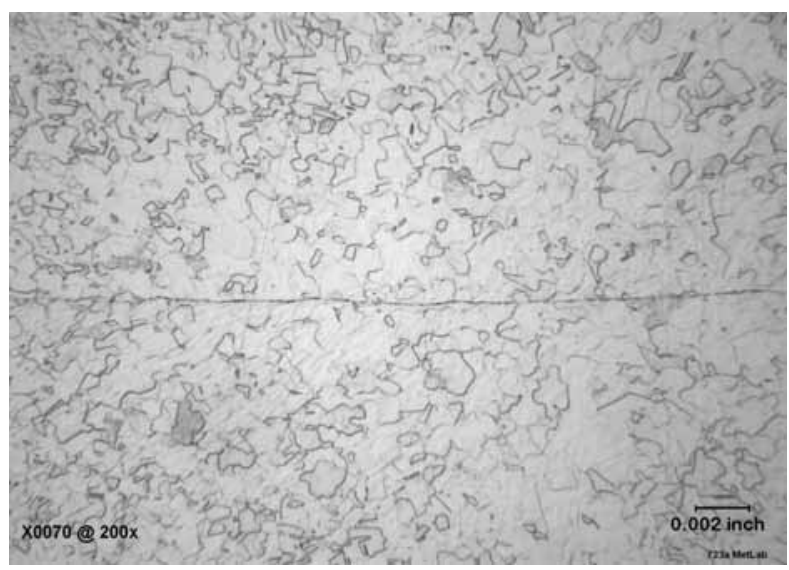

(c)

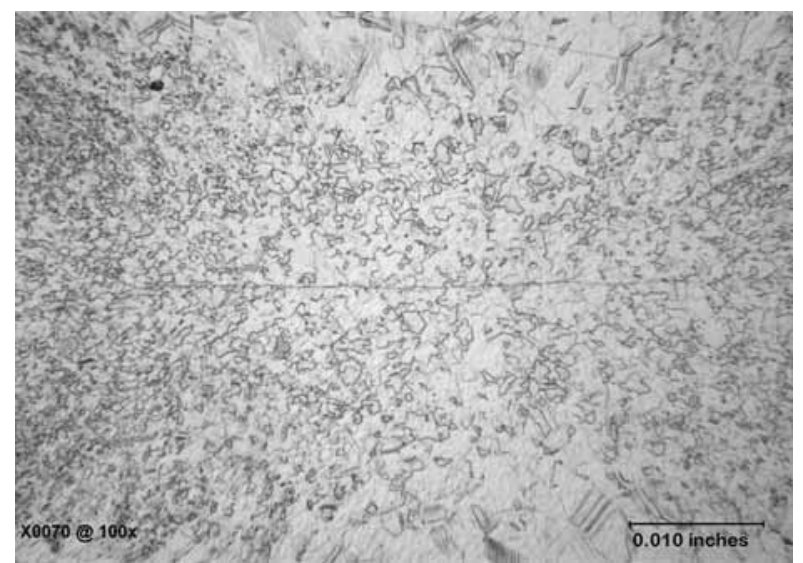

(b)

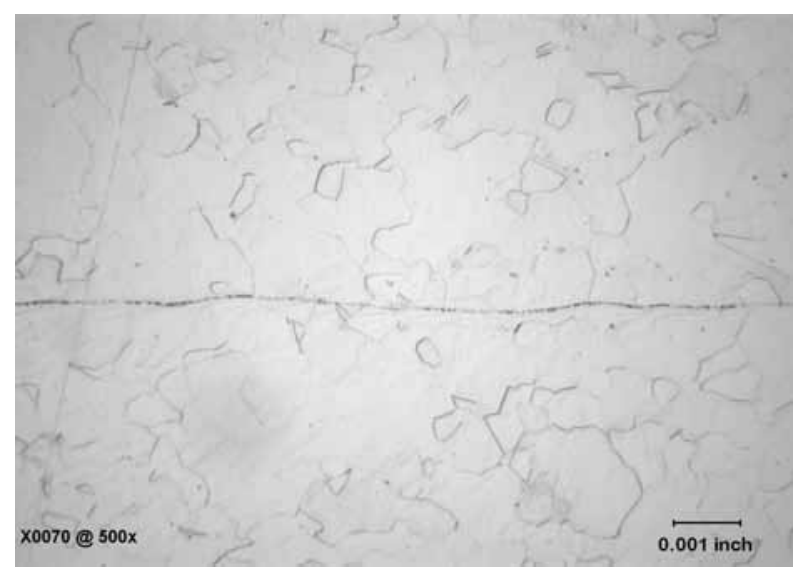

(d)

Figure 7. Sample X0070 welded in deuterium, shown at various original magnifications (a) 50X (b) 100X, (c) 200X and (d) 500X.
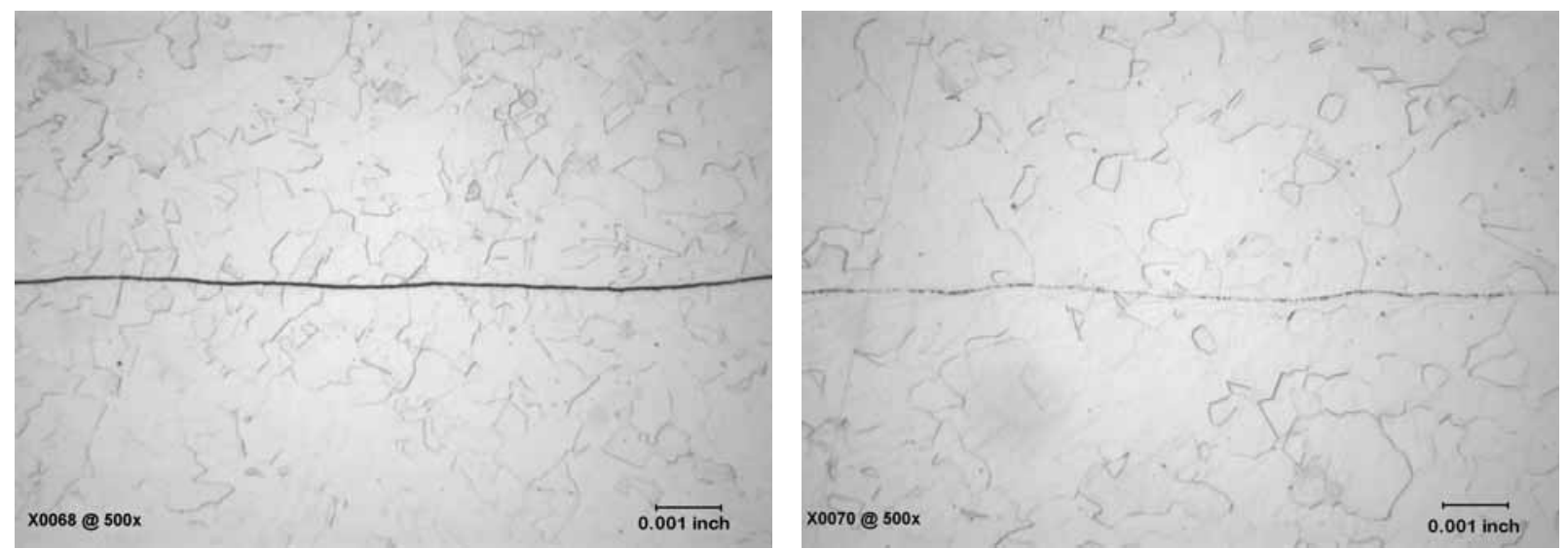

Figure 8. Simple comparison of air (a) and deuterium (b) atmospheres on weld quality. 
Comparison of Air and Deuterium on

Pinch Weld Bond Appearance

\section{Distribution}

S.L. West SRNL

S. Mazurek SRS

K Arnold KCP

J. Samayoa KCP

E.A Clark SRNL

C. Pretzel SNL

K Hicken SNL

S. Robinson SNL

B. Wilkinson LANL

D Lohmeier LANL

P. Korinko SRNL

B. West SRS

J. McCowan SRS 